This item was submitted to Loughborough's Research Repository by the author.

Items in Figshare are protected by copyright, with all rights reserved, unless otherwise indicated.

\title{
Manganese coordination chemistry of bis(imino)phenoxide derived [2 + 2] Schiff-base macrocyclic ligands
}

PLEASE CITE THE PUBLISHED VERSION

http://dx.doi.org/10.1039/c5dt03453a

\section{PUBLISHER}

(C) Royal Society of Chemistry

\section{VERSION}

AM (Accepted Manuscript)

\section{PUBLISHER STATEMENT}

This work is made available according to the conditions of the Creative Commons Attribution-NonCommercialNoDerivatives 4.0 International (CC BY-NC-ND 4.0) licence. Full details of this licence are available at: https://creativecommons.org/licenses/by-nc-nd/4.0/

\section{LICENCE}

CC BY-NC-ND 4.0

\section{REPOSITORY RECORD}

Yang, Wenxue, Ke-Qing Zhao, Bi-Qin Wang, Carl Redshaw, Mark Elsegood, Jiang-Lin Zhao, and Takehiko Yamato. 2019. "Manganese Coordination Chemistry of Bis(imino)phenoxide Derived [2 + 2] Schiff-base Macrocyclic Ligands". figshare. https://hdl.handle.net/2134/21105. 


\title{
Manganese coordination chemistry of bis(imino)phenoxide derived [2 + 2] Schiff-base macrocyclic ligands
}

\author{
Wenxue Yang, ${ }^{a}$ Ke-Qing Zhao, ${ }^{* a}$ Bi-Qin Wang, ${ }^{a}$ Carl Redshaw, ${ }^{* a, b}$ Mark R.J. Elsegood,*c Jiang-Lin \\ Zhao $^{\mathrm{d}}$ and Takehiko Yamato ${ }^{\mathrm{d}}$
}

\begin{abstract}
${ }^{a}$ College of Chemistry and Materials Science, Sichuan Normal University, Chengdu, 610066, China.
${ }^{b}$ Department of Chemistry, The University of Hull, Cottingham Rd, Hull, HU6 7RX, U.K.

${ }^{c}$ Chemistry Department, Loughborough University, Loughborough, Leicestershire, LE11 3TU, U.K.

${ }^{d}$ Department of Applied Chemistry, Saga University, Saga, 840-8502, Japan

E-mail: $\underline{\text { C.Redshaw@hull.ac.uk }}$
\end{abstract}

\begin{abstract}
The $[2+2]$ Schiff base macrocycles $\left[2,2^{\prime}-\left(\mathrm{CH}_{2} \mathrm{CH}_{2}\right)\left(\mathrm{C}_{6} \mathrm{H}_{4} \mathrm{~N}\right)_{2}-2,6-\left(4-\mathrm{RC}_{6} \mathrm{H}_{3} \mathrm{OH}\right)\right]_{2}\left(\mathbf{I}^{\mathrm{R}} \mathrm{H}_{2}\right)$, upon reaction with $\mathrm{MnCl}_{2}$ (two equivalents) afforded the bimetallic complex $\left[\mathrm{Cl}_{3} \mathrm{Mn}(\mu-\mathrm{Cl}) \mathrm{Mn}\left(\mathbf{I}^{\mathrm{Me}} \mathrm{H}_{2}\right)\right](\mathbf{1})$ or the salt complex $\left[\mathrm{Cl}_{3} \mathrm{Mn}(\mathrm{NCMe})\right]\left[\mathrm{MnCl}\left(\mathbf{I}^{\mathrm{tBu}} \mathrm{H}_{2}\right)\right]$ (2). Under similar conditions, use of the related $[2+2]$ oxy-bridged macrocycle $\left[2,2^{\prime}-\mathrm{O}\left(\mathrm{C}_{6} \mathrm{H}_{4} \mathrm{~N}=\mathrm{CH}\right)_{2} 4-\mathrm{RC}_{6} \mathrm{H}_{3} \mathrm{OH}\right]\left(\mathbf{I I}^{\mathrm{R}} \mathrm{H}_{2}\right)$, afforded the bimetallic complexes $\left[(\mathrm{MnCl})_{2} \mathrm{II}^{\mathrm{R}}\right](\mathrm{R}=\mathrm{Me} \mathrm{3,t}, \mathrm{Bu}$ 4), whilst the macrocycle derived from 1,2-diaminobenzene and 5,5'-di-tert-butyl-2,2'-dihydroxy-3,3'-methylenedibenzaldehyde $\quad\left(\mathbf{I I I H}_{4}\right)$ afforded the complex $\left[(\mathrm{MnCl})_{2}(\mathbf{I I I})\right] \cdot 2 \mathrm{MeCN} \quad(5 \cdot 2 \mathrm{MeCN})$. For comparative studies, the salt complexes $\left[2,6-(\mathrm{ArNHCH})_{2}-4-\mathrm{MeC}_{6} \mathrm{H}_{2} \mathrm{O}\right]\left[\mathrm{MnCl}_{3}(\mathrm{NCMe})\right] \quad\left(\mathrm{Ar} \quad=\quad 2,4-\mathrm{Me}_{2} \mathrm{C}_{6} \mathrm{H}_{3}, \quad 6\right)$ and $\left\{\left[2,6-(\mathrm{ArNHCH})-4-\mathrm{Me}_{6} \mathrm{C}_{6} \mathrm{H}_{2} \mathrm{O}\right] \mathrm{MnCl}\right\}_{2}\left[\mathrm{MnCl}_{4}\right] \cdot 8 \mathrm{CH}_{2} \mathrm{Cl}_{2}\left(\mathrm{Ar}=4-\mathrm{MeC}_{6} \mathrm{H}_{4}, 7 \cdot 8 \mathrm{CH}_{2} \mathrm{Cl}_{2}\right)$ were prepared. The crystal structures of $\mathbf{1}-\mathbf{7}$ are reported (synchrotron radiation was necessary for complexes $\mathbf{1}, \mathbf{3}$ and $\mathbf{5}$ ). Complexes 1 - 7 (not 5) were screened for their potential to act as pre-catalysts for the ring opening polymerization (ROP) of $\varepsilon$-caprolactone; 3, 4 and 6, 7 were inactive, whilst 1 and 2 exhibited only poor activity with low conversion $(<15 \%)$ at temperatures above $60{ }^{\circ} \mathrm{C}$.
\end{abstract}




\section{Introduction}

Over the last decade, there has been a great deal of interest in the chemistry of frameworks that are capable of binding two transition metals in close proximity, due primarily to the possibilities of beneficial cooperative effects. [1] Macrocycles bearing phenoxide groups as well as accessible nitrogen centres have attracted attention, particularly from groups with biological interests, because of their controllable coordination chemistry which has allowed for the study of structure-bioactivity relationships. [2] We have previously investigated the use Schiff-base macrocycles of type $\mathrm{IH}_{2}$, which are related to the much studied Robson-type macrocycles, [3] and have observed interesting structure/activity trends for organoaluminium complexes in the ring opening polymerization (ROP) of $\varepsilon$-caprolactone. [4] The metal coordination chemistry of this particular ligand set is unexplored, indeed a search of the CSD revealed no hits other than the structure of the parent pro-ligand $\mathbf{I H}_{2}$ and a methylated derivative thereof. [5] Given this, we have initiated a programme to explore their transition metal chemistry, and have also extended our studies to include the related macrocycles $\mathbf{I I H}_{2}$ and $\mathbf{I I I H}_{4}$ (see scheme 1). We report here our initial studies on the manganese coordination chemistry of $\mathbf{I H}_{2}-\mathbf{I I I H}_{4}$, and report the molecular structures of five new complexes. A search of the CSD for manganese bound in ' $N, O$ fashion' to a phenoxide motif bearing ortho imine groups revealed 116 hits. [6] We note that a number of dinuclear manganese complexes are of catalytic interest given their potential for catecholase activity, [7] whilst manganese Schiff-base complexes have also attracted attention for their antibacterial properties, [8] and have also been extensively employed in organic chemistry, for example as catalysts for asymmetric epoxidation. [9] As mentioned above, our interest stems from exploring the use of earth abundant transition metals as the metal centres in pre-catalysts for ROP, and herein, we have screened the manganese complexes for their ability to act as pre-catalysts in the ring opening polymerization (ROP) of $\varepsilon$-caprolactone; there is a lack of other Mn-based systems utilized in ROP of cyclic esters. [10] 

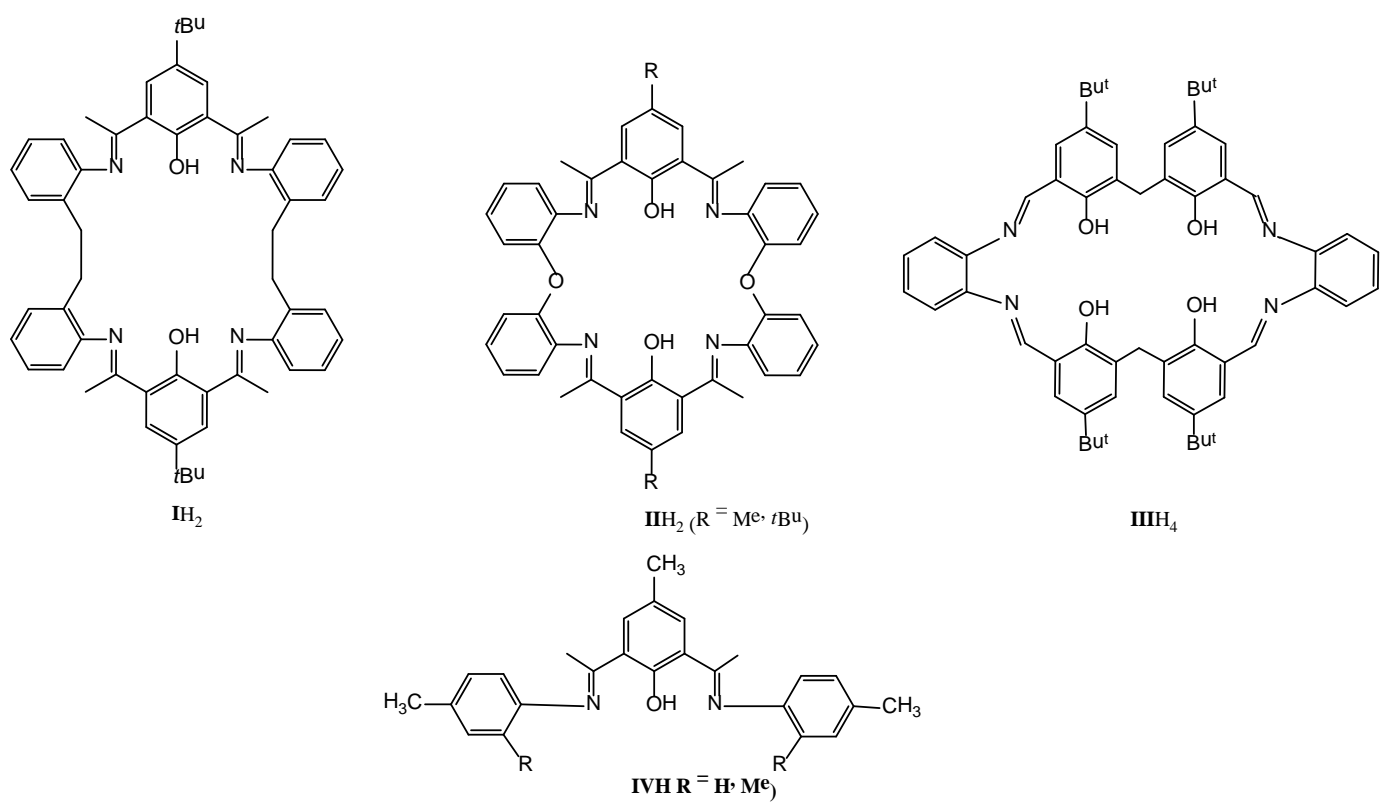

$\mathrm{IIIH}_{4}$
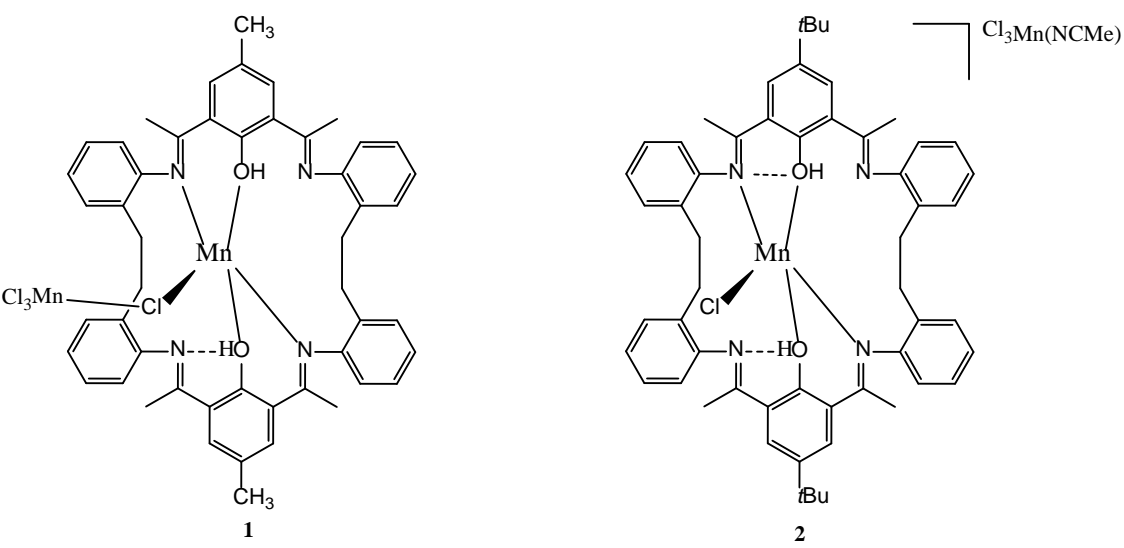

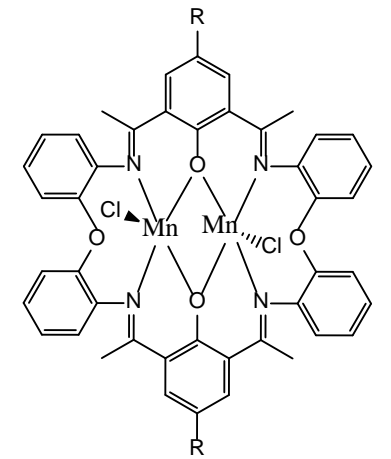

$\left.3(\mathrm{R}=\mathrm{Me}) ; \mathbf{4}_{(\mathrm{R}}=\mathrm{tBu}\right)$

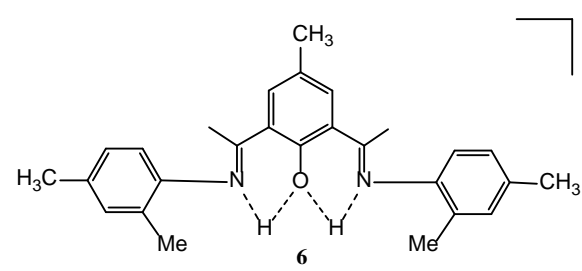

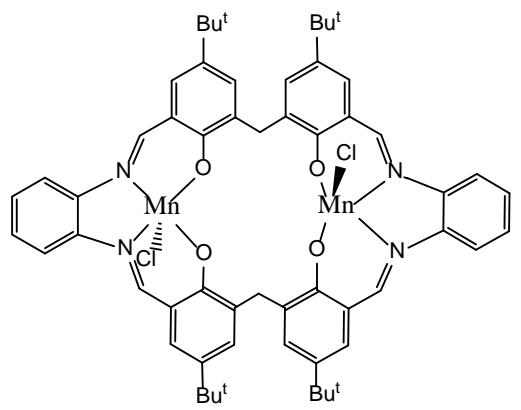

5

$\mathrm{MnCl}_{3}(\mathrm{NCMe}) \quad\left[\mathrm{Mn}(\mathrm{LH})_{2}\left(\mu^{-} \mathrm{Cl}\right)\right]_{2}\left[\mathrm{MnCl}_{4}\right]$

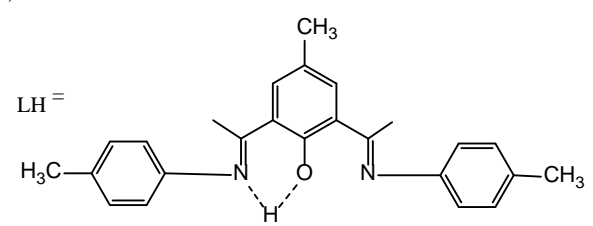

Scheme 1 


\section{Results and Discussion}

\section{Use of $\left\{2,2-\left(\mathrm{CH}_{2} \mathrm{CH}_{2}\right)\left(\mathrm{C}_{6} \mathrm{H}_{4} \mathrm{NH}_{2}\right)_{2}\right\}$}

The neutral [2 + 2] macrocycle $\left[2,2^{\prime}-\left(\mathrm{CH}_{2} \mathrm{CH}_{2}\right)\left(\mathrm{C}_{6} \mathrm{H}_{4} \mathrm{~N}\right)_{2}-2,6-\left(4-\mathrm{MeC}_{6} \mathrm{H}_{3} \mathrm{OH}\right)\right]_{2}\left(\mathbf{I}^{\mathrm{Me}} \mathrm{H}_{2}\right)$ prepared from the diamine $\left\{2,2^{\prime}-\left(\mathrm{CH}_{2} \mathrm{CH}_{2}\right)\left(\mathrm{C}_{6} \mathrm{H}_{4} \mathrm{NH}_{2}\right)_{2}\right\}$ and 2,6-diformyl-4-methylphenol [1,3-(CHO) $\left.)_{2}-5-\mathrm{MeC}_{6} \mathrm{H}_{3} \mathrm{OH}-2\right]$ in refluxing ethanol in the presence of the Lewis acid $\mathrm{B}(\mathrm{OMe})_{3}$, was treated with two equivalents of $\mathrm{MnCl}_{2}$ in refluxing toluene. Following work-up (see experimental), the orange complex $\left[\mathrm{Cl}_{3} \mathrm{Mn}(\mu-\mathrm{Cl}) \mathrm{Mn}\left(\mathrm{I}^{\mathrm{Me}}\right) \mathrm{H}_{2}\right]$ (1) was isolated in moderate yield (ca. $35 \%$ ). The IR spectrum contained a strong band a $1635 \mathrm{~cm}^{-1}$ assigned to $v(\mathrm{C}=\mathrm{N})$. Small crystals of $\mathbf{1} \cdot 3 \mathrm{MeCN}$ suitable for X-ray diffraction using synchrotron radiation were grown from acetonitrile at $0{ }^{\circ} \mathrm{C}$. The macrocycle adopts a twisted conformation to accommodate two intramolecular H-bonds, see Figure 1 and Table S1 (ESI). The 'central' manganese [Mn(1)] possesses a trigonal bipyramidal geometry with phenoxy oxygen atoms axial and a chloride and two imine nitrogens in equatorial positions. The 'outer' manganese $[\mathrm{Mn}(2)]$ is distorted tetrahedral, and is linked to $\mathrm{Mn}(1)$ via a bridging chloride [Cl(1)]. The $\mathrm{Mn}-\mathrm{O}($ phenoxide) bond lengths [2.0752(15) and 2.0954(15) $\AA$ ] are slightly shorter than the $\mathrm{Mn}^{\mathrm{II}}$ - phenoxide bonds [2.1583(19) - 2.374(2) $\AA$ ] observed in recently reported mixed-valance $\mathrm{Mn}^{\mathrm{II}} / \mathrm{Mn}^{\mathrm{III}}$ complexes of the Robson-type macrocycle derived from 2,6-diformyl-4-methylphenol and 2,2-dimethyl-1,3-diaminopropane [7b], whilst the $\mathrm{Mn}-\mathrm{N}_{\text {imine }}$ bond lengths [2.1959(17) and 2.2077(19) $\AA$ ] compare favourably with those observed in said mixed-valence complexes [2.161(2) - 2.240(3) $\AA$ ]. The planar section of the macrocycle from C(1) to C(14) forms a $\pi \cdots \pi$ stack with an inversion related planar section on the next molecule with contacts in the range 3.29-3.51 (see Figure S1, ESI). In the packing of $\mathbf{1} \cdot 3 \mathrm{MeCN}$, there are weak intermolecular interactions, e.g. $\mathrm{C}(31)-\mathrm{H}(31)^{\cdots} \mathrm{Cl}(2) 2.61 \AA$ (hydrogen bond geometries are given in Table S1, ESI). 


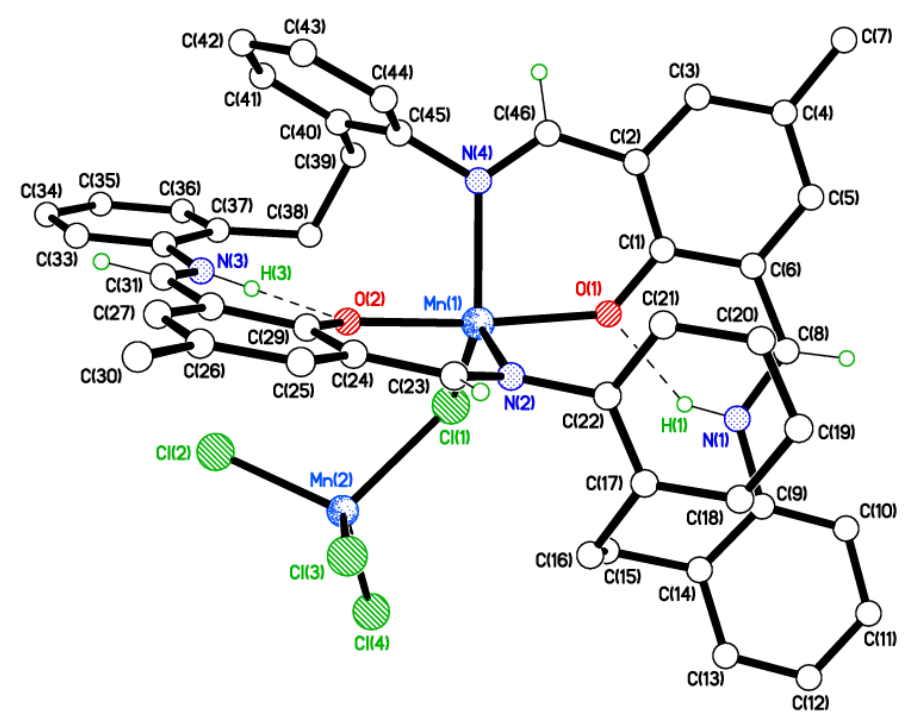

Figure 1. Molecular structure of $\left[\mathrm{Cl}_{3} \mathrm{Mn}(\mu-\mathrm{Cl}) \mathrm{Mn}\left(\mathbf{I}^{\mathrm{Me}}\right) \mathrm{H}_{2}\right](\mathbf{1})$. Selected bond lengths $(\AA)$ and angles $\left(^{\circ}\right)$ : $\mathrm{Mn}(1)-\mathrm{O}(1)$ 2.0954(15), Mn(1) - O(2) 2.0752(15), Mn(1) - N(2) 2.1959(17), Mn(1) - N(4) 2.2077(19), Mn(1) - Cl(1) 2.4492(7), Mn(2) - Cl(1) 2.4659(7), $\mathrm{Mn}(2)-\mathrm{Cl}(2)$ 2.3542(7), Mn(2) - Cl(3) 2.3430(7), $\mathrm{Mn}(2)$ - Cl(4) 2.3502(8); O(1) - Mn(1) - O(2) 173.94(6), Mn(1) - Cl(1) - Mn(2) 109.02(2), N(4) - Mn(1) $-\operatorname{Cl}(1)$ 119.39(5).

Use of the related 2,6-diformyl-4-tert-butylphenol [1,3-(CHO) $\left.)_{2}-5-t \mathrm{BuC}_{6} \mathrm{H}_{3} \mathrm{OH}-2\right]$ in the macrocycle synthesis under the same conditions afforded $\mathbf{I}^{\mathrm{tBu}} \mathrm{H}_{2}$ and subsequent treatment with $\mathrm{MnCl}_{2}$ led to the isolation of the salt complex $\left[\mathrm{Cl}_{3} \mathrm{Mn}(\mathrm{NCMe})\right]\left[\mathrm{MnCl}\left(\mathrm{I}^{\mathrm{tBu}} \mathrm{H}_{2}\right)\right](2)$ in moderate yield (ca. $\left.55 \%\right)$. The IR spectrum contained a strong band a $1634 \mathrm{~cm}^{-1}$ assigned to $v(\mathrm{C}=\mathrm{N})$. Crystals suitable for X-ray diffraction were obtained from acetonitrile on prolonged standing at ambient temperature. The molecular structure is shown in Figure 2, with selected bond lengths and angles given in the caption. There is one molecule of the complex in the asymmetric unit, but no solvent of crystallization. The major difference from $\mathbf{1}$ is that $\operatorname{Mn}(2)$ is not linked to $\mathrm{Mn}(1)$ via a bridging chloride. The reason for this is thought to be the presence of the bulky tert-butyl group at the para position of the phenoxide of the macrocycle. However, similar to $\mathbf{1}$, there are two intramolecular H-bonds involving the phenoxide oxygens. The Mn - O(phenoxide) bond lengths in 2 [2.0712(13) and 2.0803(14) $\AA$ ] and the Mn - N(imine) bond lengths [2.2359(18) and 2.2328(17) $\AA$ ] are 
close to those observed for $\mathbf{1}$. In $2 \mathrm{Mn}(1)$ also adopts a trigonal bi-pyramidal geometry with phenoxide oxygens axial. EPR spectra for $\mathbf{1}$ and $\mathbf{2}$ recorded as powdered samples at $110 \mathrm{~K}$ are similar with a broad feature at around ca. $\mathrm{g}=2.0$, for example see Figures. S2 and S3, ESI.

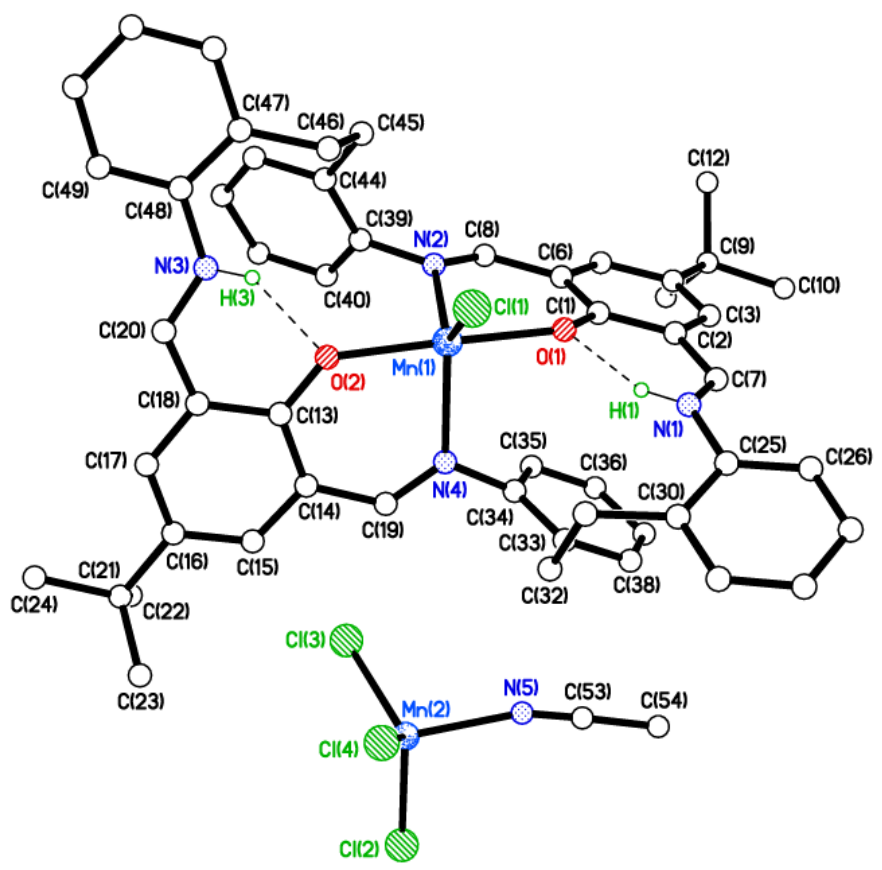

Figure 2. Molecular structure of $\left[\mathrm{Cl}_{3} \mathrm{Mn}(\mathrm{NCMe})\right]\left[\mathrm{MnCl}\left(\mathrm{I}^{\mathrm{tBu}}\right) \mathrm{H}_{2}\right](2)$. Selected bond lengths $(\AA)$ and angles $\left(^{\circ}\right): M n(1)-O(1)$ 2.0712(13), Mn(1) - O(2) 2.0803(14), Mn(1) - N(2) 2.2359(18), Mn(1) - N(4) 2.2328(17), $\operatorname{Mn}(1)$ - Cl(1) 2.3860(6), $\operatorname{Mn}(2)$ - Cl(2) 2.3269(8), Mn(2) - Cl(3) 2.3241(7), Mn(2) - Cl(4) 2.3043(9); O(1) - Mn(1) - O(2) 173.72(6), N(4) - Mn(1) - Cl(1) 122.79(5).

\section{Use of $2,2-\mathrm{O}\left(\mathrm{C}_{6} \mathrm{H}_{4} \mathrm{NH}_{2}\right)_{2}$}

The $[2+2]$ macrocycle $\left[2,2^{\prime}-\mathrm{O}\left(\mathrm{C}_{6} \mathrm{H}_{4} \mathrm{~N}=\mathrm{CH}\right)_{2} 4-\mathrm{MeC}_{6} \mathrm{H}_{3} \mathrm{OH}\right]\left(\mathbf{I I}^{\mathrm{R}} \mathrm{H}_{2}\right)$, prepared from the diamine $2,2^{\prime}-\mathrm{O}\left(\mathrm{C}_{6} \mathrm{H}_{4} \mathrm{NH}_{2}\right)_{2}$ and $\left[1,3-(\mathrm{CHO})_{2}-5-\mathrm{R}^{\prime} \mathrm{C}_{6} \mathrm{H}_{3} \mathrm{OH}-2\right]\left(\mathrm{R}^{\prime}=\mathrm{Me}, t \mathrm{Bu}\right)$ in refluxing ethanol, on treatment with $\mathrm{MnCl}_{2}$ in refluxing toluene affords the yellow complexes $\left[(\mathrm{MnCl})_{2} \mathbf{I I}^{\mathrm{Me}}\right](\mathbf{3})$ or $\left[(\mathrm{MnCl})_{2} \mathbf{I I}^{\mathrm{tBu}}\right](\mathbf{4})$, respectively. The IR spectra of 3 and 4 contained a strong band at $1625 \mathrm{~cm}^{-1}$ assigned to $v(\mathrm{C}=\mathrm{N})$. Small crystals of $3 \cdot \mathrm{C}_{3} \mathrm{H}_{6} \mathrm{O}$ suitable for an $\mathrm{X}$-ray study using synchrotron radiation were grown from acetone at ambient temperature. There is one acetone of crystallization in the asymmetric unit, which is not in contact 
with the $\mathrm{Mn}_{2}$ unit. The structure is shown in Figure 3 and reveals how the macrocycle is 'pinched' to accommodate coordination of the two severely distorted trigonal bi-pyramidal manganese centres. Atoms $\mathrm{N}(1) / \mathrm{O}(3)$ are axial at $\mathrm{Mn}(1)$ and $\mathrm{O}(1) / \mathrm{N}(3)$ are axial at $\mathrm{Mn}(2)$. The $\mathrm{Mn}-\mathrm{O}$ (phenoxide) bond lengths in 3. $\mathrm{C}_{3} \mathrm{H}_{6} \mathrm{O}$ [2.120(3) and 2.183(3) $\AA$ ] are slightly longer than observed in $\mathbf{1}$ and 2, but slightly shorter than those observed by Mohanta et al. in their mixed valence systems. [7b]

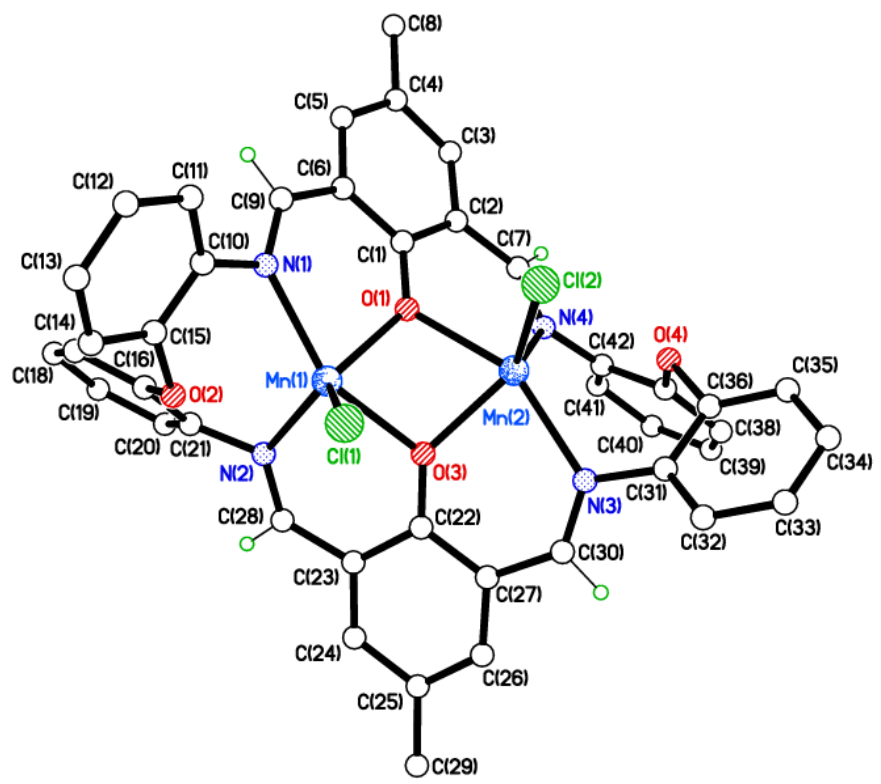

Figure 3. Molecular structure of $\left[(\mathrm{MnCl})_{2} \mathbf{I I}^{\mathrm{Me}}\right] \cdot \mathrm{C}_{3} \mathrm{H}_{6} \mathrm{O}\left(3 \cdot \mathrm{C}_{3} \mathrm{H}_{6} \mathrm{O}\right)$. Selected bond lengths $(\AA)$ and angles $\left(^{0}\right): \mathrm{Mn}(1)-\mathrm{O}(1)$ 2.120(3), $\mathrm{Mn}(1)-\mathrm{O}(3)$ 2.183(3), $\mathrm{Mn}(1)-\mathrm{N}(1)$ 2.206(4), $\mathrm{Mn}(1)-\mathrm{N}(2)$ 2.203(4), $\mathrm{Mn}(1)-$ $\mathrm{Cl}(1)$ 2.3464(14); O(1) - Mn(1) - O(3) 71.89(12), Mn(1) - O(1) - Mn(2) 96.22(12), N(1) - Mn(1) - N(2) 111.16(15).

If the complex is recrystallized from acetonitrile, then a different crystal system results, and in this case the asymmetric unit contains four molecules of acetonitrile. However, the two metal complexes have similar conformations, with chlorides on the same side in both cases (emphasized in Figure 4). The Mn O(phenoxide) [O(1) 2.1322(13) and 2.2384(14) $\AA$ ] and Mn - N(imine) [2.2060(17) and 2.2468(17) $\AA$ ] bond lengths are as expected for $\mathrm{Mn}^{\mathrm{II}}$. [7b, 11] The aceonitrile molecules either reside in the cleft of the molecule [those containing $\mathrm{N}(5)$ and $\mathrm{N}(6)$ ] or lie between molecules (exo). The acetonitrile containing $\mathrm{N}(5)$ 
also forms a weak $\mathrm{C}-\mathrm{H}^{\cdots} \cdots \mathrm{N}$ H-bond with $\mathrm{C}\left(7^{\prime}\right)-\mathrm{H}\left(7^{\prime}\right)$ on an adjacent molecule at 2.53 Å. Molecules stack in columns along the $a$ axis via centrosymmetric weak $\pi \cdots \pi$ interactions between 'tolyl' rings (see Figure S4, ESI). The Mn $\cdots$ Mn distances in 3 $\mathrm{C}_{3} \mathrm{H}_{6} \mathrm{O}$ and 3 $4 \mathrm{MeCN}$ are 3.1983(10) and 3.3347(4) $\AA$, respectively.

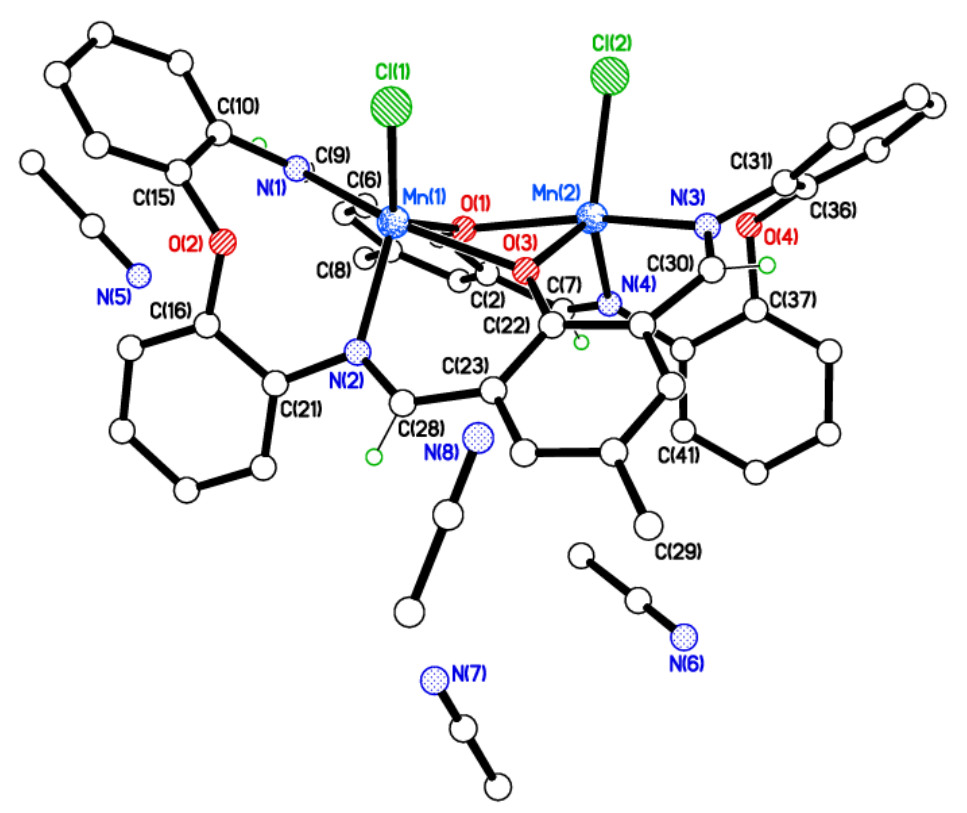

Figure 4. Molecular structure of $\left[(\mathrm{MnCl})_{2} \mathbf{I I}^{\mathrm{Me}}\right] \cdot 4 \mathrm{MeCN}(3 \cdot 4 \mathrm{MeCN})$. Selected bond lengths $(\AA)$ and angles $\left({ }^{0}\right): \mathrm{Mn}(1)-\mathrm{O}(1)$ 2.1322(13), $\mathrm{Mn}(1)-\mathrm{O}(3)$ 2.2384(14), Mn(1) - N(1) 2.2468(17), Mn(1) - N(2) 2.2060(17), $\mathrm{Mn}(1)-\mathrm{Cl}(1)$ 2.3639(6); O(1) - Mn(1) - O(3) 72.95(5), Mn(1) - O(1) - Mn(2) 101.50(6), N(1) - Mn(1) - N(2) 112.88(6). 


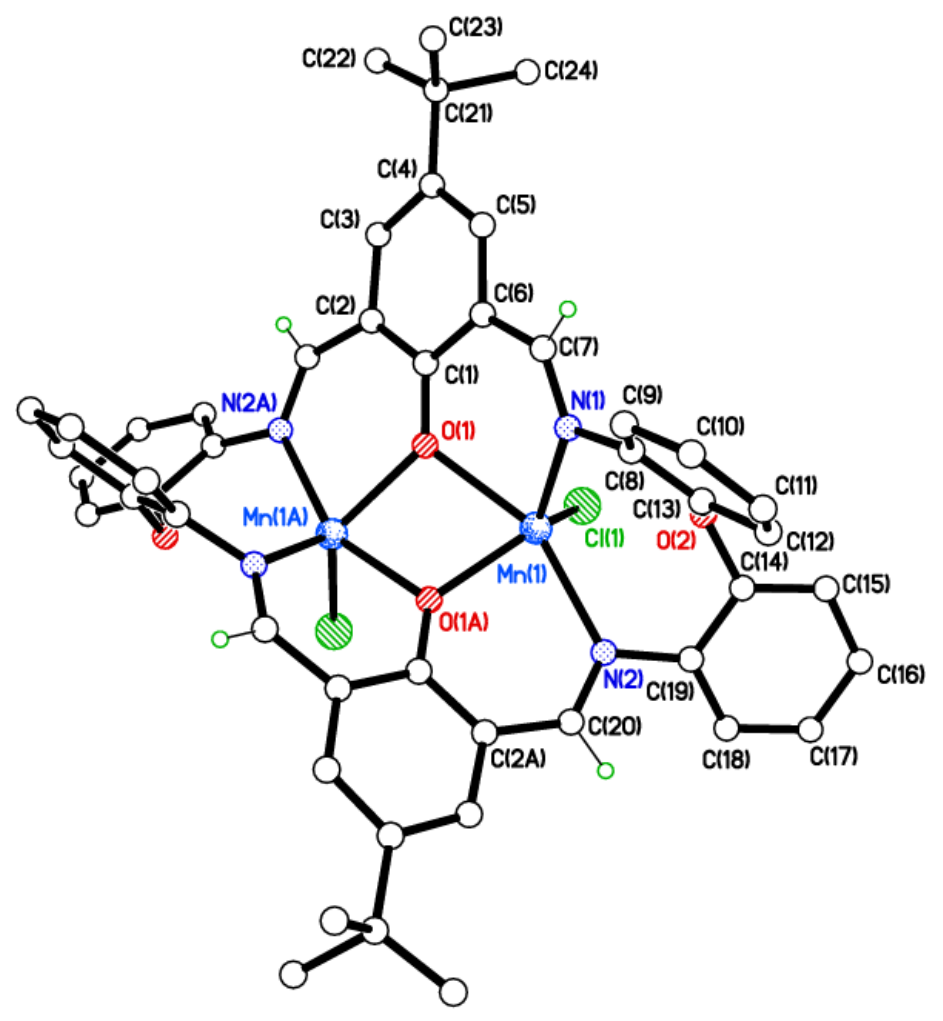

Figure 5. Molecular structure of $\left[(\mathrm{MnCl})_{2} \mathbf{I I}^{\mathrm{tBu}}\right](4)$. Selected bond lengths $(\AA)$ and angles $\left({ }^{0}\right)$ : $\mathrm{Mn}(1)-\mathrm{O}(1)$ 2.2270(17), Mn(1) - O(1A) 2.1078(15), Mn(1) - N(1) 2.193(2), Mn(1) - N(2) 2.270(2), Mn(1) - Cl(1) 2.3571(9); O(1) - Mn(1) - O(1A) 73.26(7), Mn(1) - O(1) - Mn(1A) 100.80(7), N(1) - Mn(1) - N(2) 112.92(8).

In the case of the related macrocycle derived from 2,6-diformyl-4-tert-butylphenol, reaction with $\mathrm{MnCl}_{2}$ and similar work-up led to the isolation of the complex $\left[(\mathrm{MnCl})_{2} \mathbf{I}^{\mathrm{tBu}}\right](4)$ in moderate isolated yield (50 \%). Crystals of $\mathbf{4} \cdot \mathrm{MeCN}$ suitable for an X-ray study were grown from acetonitrile at ambient temperature. The molecular structure is shown in Figure 5, with selected bond lengths and angles given in the caption. The molecule lies on a two-fold axis. The methyl groups on the $t \mathrm{Bu}$ group at $\mathrm{C}(21)$ are disordered over two sets of positions; major component 52.8(7) \%. As for the solvates of 3, the manganese centres in 4 adopt distorted trigonal bi-pyramidal geometries. The Mn $\cdots$ Mn distance in 4 is 3.3408(8) $\AA$. The MeCN of crystallisation resides in large voids between dimer complexes and was severely disordered [See X-ray 
Crystallography section]. Molecules stack in columns along the $b$ direction (see Figure S5, ESI). The solvent-filled voids lie in layers in the $b / c$ plane. EPR spectra for $\mathbf{3}$ and $\mathbf{4}$, recorded as powdered samples at ambient temperature (298 K), are again dominated by broad features at g = 2.00 (for 3) or 2.05 (for 4) (see Figures S6 and S7, ESI). Broad features in X-band in the $\mathrm{g}=2$ region have been observed previously for dinuclear $\mathrm{Mn}(\mathrm{II})$ complexes, for example the $\mu$-phenoxo-bis- $\mu$-acetato complex $\left[(\mathrm{Bpmp}) \mathrm{Mn}_{2}(\mu \text {-OAc })_{2}\right]^{+}$ (BpmpH = 2,6-bis[bis(2-pyridylmethyl)aminomethyl]-4-methylphenol). [12]

Interaction of the macrocycle $\mathbf{I I I H}_{4}$ derived from 1,2-diaminobenzene and 5,5'-di-tert-butyl-2,2'-dihydroxy-3,3'-methylenedibenzaldehyde afforded the complex $\left[(\mathrm{MnCl})_{2}(\mathbf{I I I})\right] \cdot 2 \mathrm{MeCN}(5 \cdot 2 \mathrm{MeCN})$, for which small orange/brown crystals could be grown from a saturated acetonitrile solution at ambient temperature. The diffraction data were collected using synchrotron radiation. The molecular structure is shown in Figure 6. Half of the formula is unique, with the metal complex on a centre of symmetry. In this case each manganese centre is best described as adopting a square-based pyramidal geometry ( $c f$ trigonal bipyramidal geometries for the other complexes herein) with the chloride as the apex; each Mn centre is displaced by 0.325(3) $\AA$ out of the $\mathrm{N}_{2} \mathrm{O}_{2}$ plane. The chlorine atoms lie on opposite sides of the molecule. The $\mathrm{Mn}-\mathrm{O} / \mathrm{N}$ bonds in $\mathbf{5}$ are all significantly shorter than in the

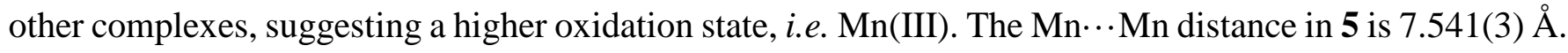
In the packing of 5, head-to-tail weak $\mathrm{C}-\mathrm{H} \cdots \mathrm{Cl}$ interactions exist between molecules giving rise to chains along the $c$ axis (see Figure 7). 


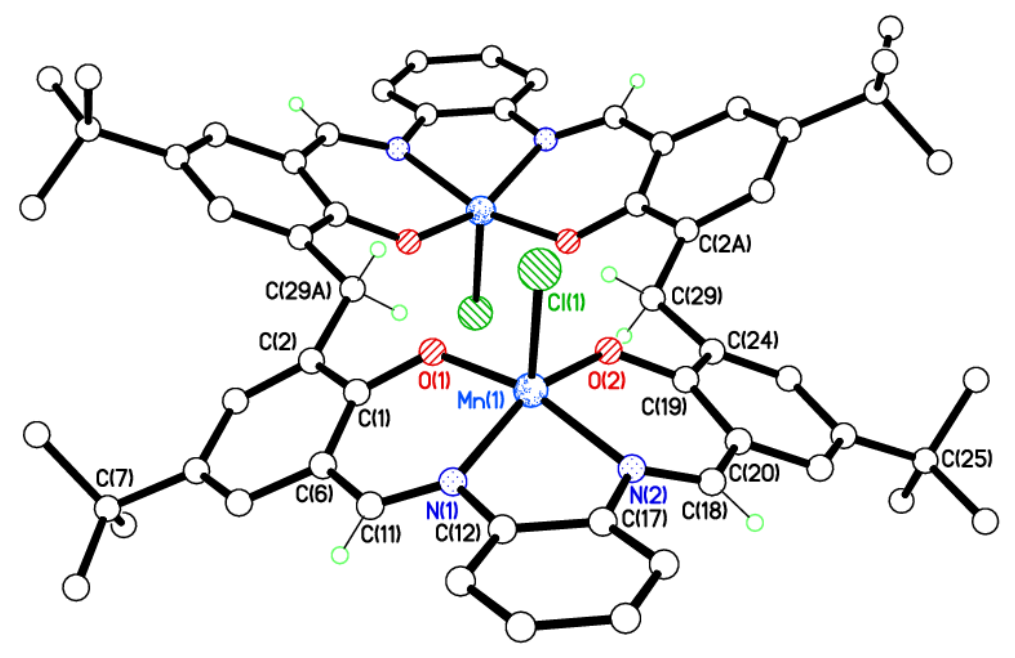

Figure 6. Molecular structure of $\left[(\mathrm{MnCl})_{2}(\mathrm{III})\right](5 \cdot 2 \mathrm{MeCN})$. Selected bond lengths $(\AA)$ and angles $\left({ }^{0}\right)$ : $\mathrm{Mn}(1)-\mathrm{O}(1)$ 1.849(4), Mn(1) - O(2) 1.871(4), Mn(1) - N(1) 1.986(4), Mn(1) - N(2) 2.000(5), Mn(1) $\mathrm{Cl}(1)$ 2.379(2); O(1) - Mn(1) - O(2) 92.54(19), N(1) - Mn(1) - N(2) 81.26(19).

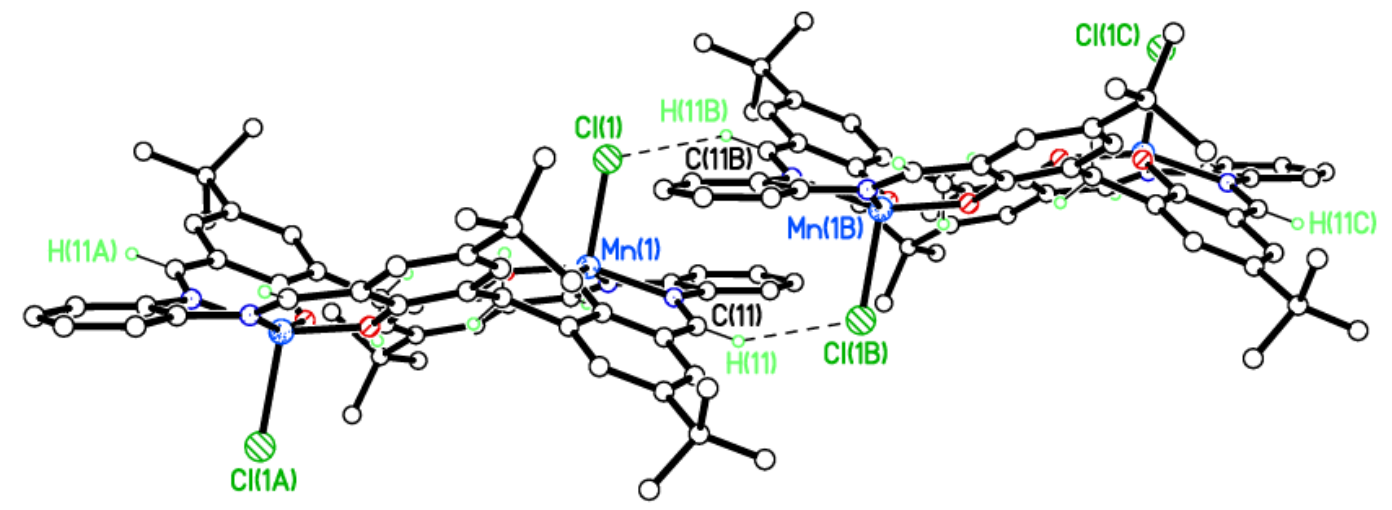

Figure 7. View of 5 showing weak, head-to-tail $\mathrm{C}-\mathrm{H} \cdots \mathrm{Cl} \mathrm{H}$-bond interactions between molecules which give rise to chains along the $c$ axis.

Salt complexes 


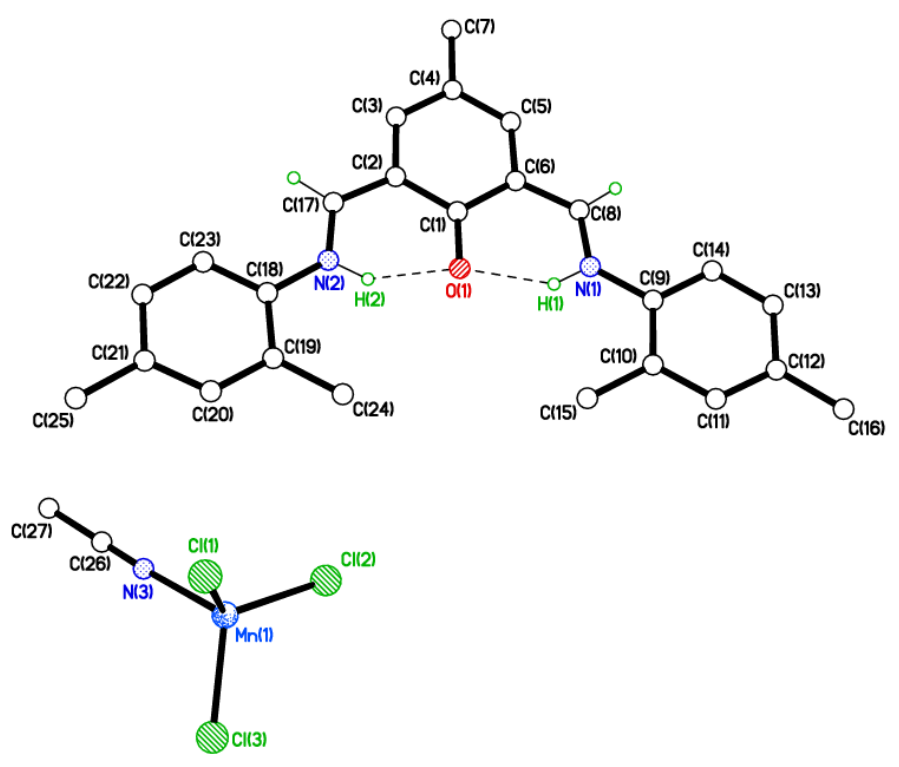

Figure 8. View of the salt 6. Selected bond lengths ( $)$ : $\mathrm{Mn}(1)-\mathrm{Cl}(1) 2.3344(5), \mathrm{Mn}(1)-\mathrm{Cl}(2) 2.3137(5)$,

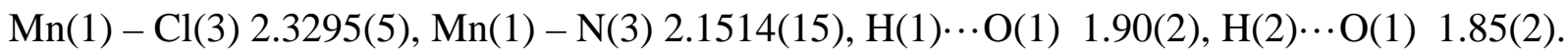

For structural and catalytic comparisons, the coordination chemistry of bis(imino)phenols of type IVH (see scheme 1) with manganese dichloride has also been investigated. Use of the bis(imino)phenol bearing aryl groups at nitrogen with a 2,4-dimethyl pattern on reaction with $\mathrm{MnCl}_{2}$, resulted in an ion-pair complex, namely [2,6-( $\left.\mathrm{ArNHCH})_{2}-4-\mathrm{MeC}_{6} \mathrm{H}_{2} \mathrm{O}\right]\left[\mathrm{MnCl}_{3}(\mathrm{NCMe})\right]$ (6) ( $\left.\mathrm{Ar}=2,4-\mathrm{Me}_{2} \mathrm{C}_{6} \mathrm{H}_{3}\right)$. Related ion-pair complexes have been reported by Sun et al when using $\mathrm{FeCl}_{3}$. [13] Salt 6 can be readily crystallized from $\mathrm{MeCN}$ at $0{ }^{\circ} \mathrm{C}$, and the structure is shown in Figure 8, with selected bond lengths and angles given in the caption. In the essentially planar cation, both nitrogen atoms are involved in H-bonding to the phenolic oxygen. The cations stack parallel to $a$, and form six weak $\mathrm{C}-\mathrm{H}^{\cdots} \mathrm{Cl}$ interactions with four different anions (see Figure S9, ESI for diagram and Table S2 for details of $\pi-\pi$ contacts).

Given in the related iron(III) chemistry, use of an aryl group bearing no ortho substituents results in a complex rather than an ion-pair, [13] we attempted the same reaction using $p$-tolylamine. However, unlike the iron case, an orange salt complex 7, structurally different to 6, was isolated. Single crystals were grown from a saturated dichloromethane solution, which proved to be weakly diffracting and twinned [See X-ray Crystallography section]. However, despite this, the structurally connectivity is clear and the salt complex 
can be formulated as $\left\{\left[2,6-(\mathrm{ArNHCH})-4-\mathrm{Me}-\mathrm{C}_{6} \mathrm{H}_{2} \mathrm{O}\right] \mathrm{MnCl}\right\}_{2}\left[\mathrm{MnCl}_{4}\right] \cdot 8 \mathrm{CH}_{2} \mathrm{Cl}_{2} \quad\left(\mathrm{Ar}=4-\mathrm{MeC}_{6} \mathrm{H}_{4}\right.$, $7 \cdot 8 \mathrm{CH}_{2} \mathrm{Cl}_{2}$ ). This salt lies on a two-fold axis, and so half is unique. Figure 9 reveals the nature of the bis(chloro)-bridged dimer, in which each manganese centre is distorted octahedral, and is bound by two protonated L type ligands each of which binds in $\mathrm{N}, \mathrm{O}$-bi-dentate fashion. Chloride bridging completes the octahedral environment and in each case the bridging chlorides are trans to a nitrogen of a chelate; the 'free' nitrogen is involved in intramolecular H-bonding with the phenoxide oxygen within the same unique chelate. The $\mathrm{Mn}-\mathrm{Cl}$ bonds of the cation are about $2.54 \AA$, whilst those of the anion are $c a$. $2.36 \AA$; both match examples in the CSD. [13] The Mn - O distances [ca. 2.09 $\AA$ ] and Mn - N distances [ca. $2.30 \AA$ ] are typical and consistent with the presence of Mn(II) centres. [7b, 11, 14]
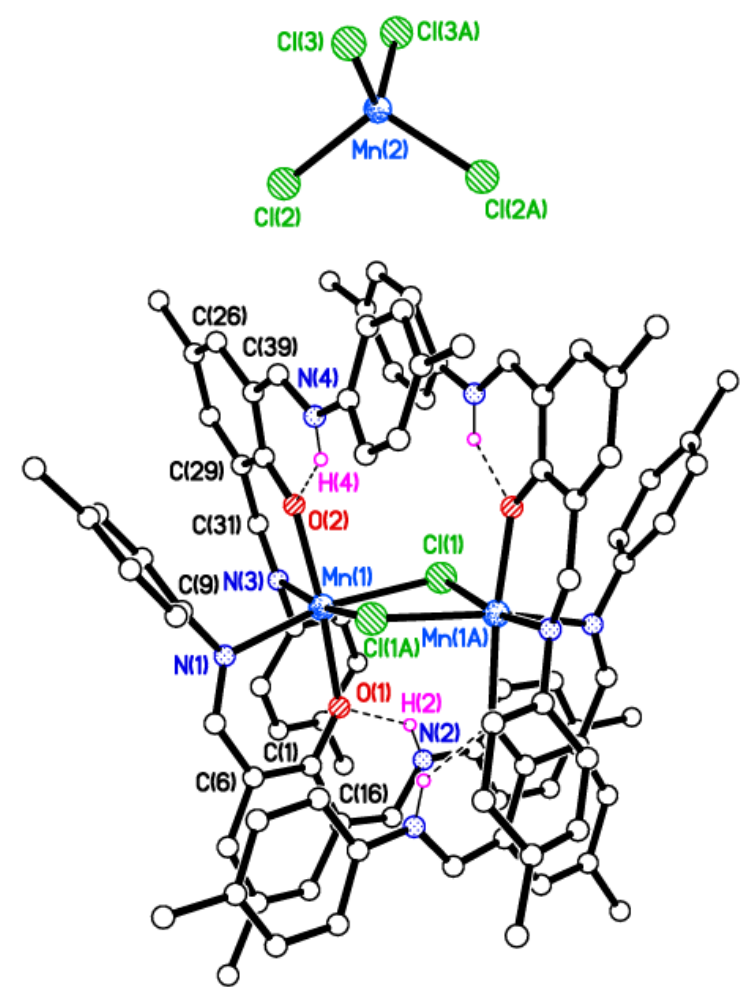

Figure 9. Molecular structure of salt complex 7; $8 \mathrm{CH}_{2} \mathrm{Cl}_{2}$ molecules of crystallisation omitted for clarity.

\section{Ring opening polymerization}

Complexes $\mathbf{1}$ - 7 (not 5) have been screened for their ability to ring open polymerize $\varepsilon$-caprolactone in the presence of benzyl alcohol $(\mathrm{BnOH})$. For comparison, the salt complexes $\mathbf{6}$ and $\mathbf{7}$ have also been 
investigated. Compound 2 was used to optimize the polymerization conditions and the results are presented in Table 1. Despite the good control (PDIs < 1.03), poor conversions were obtained $(10.2-134 \%)$ at all temperatures in the range 60 to $110{ }^{\circ} \mathrm{C}$ (runs 3, 6 and 7), with little advantage on prolonging the reaction time to $48 \mathrm{~h}$ (run 5), changing the molar ratio of $\varepsilon$-caprolactone to pre-catalyst/BnOH (runs 8 - 12) or even on changing the temperature. Results for $\mathbf{1}$ were similarly disappointing (runs 12 and 13); the yields and observed molecular weights $\left(M_{\mathrm{n}}\right)$ for $\mathbf{2}$ over 12 and $24 \mathrm{~h}$ were lower than found for $\mathbf{1}$. The use of complexes $\mathbf{3}$ or $\mathbf{4}$ led to no isolable product. The salt complexes $\mathbf{6}$ and $\mathbf{7}$ were similarly inactive. Conducting the runs in a solvent other than toluene, such as THF or $\mathrm{CH}_{2} \mathrm{Cl}_{2}$, gave no improvement in the observed catalytic activities. In general, the resulting polymer molecular weights were much lower than expected, which indicates that, in most cases, there were significant trans-esterification reactions occurring. However, given the disappointing conversions observed herein, further analysis of the activity trends and resultant PCL was not conducted. [15] We note that the use of manganese complexes as catalysts for $\alpha$-olefin polymerization has met with similar poor results. [16]

Table 1. Ring opening polymerization screening using $\mathbf{1}-\mathbf{4}$.

\begin{tabular}{ccccccccc}
\hline Run & Complex & CL: M: BnOH & T/ ${ }^{\circ} \mathrm{C}$ & $\mathrm{t} / \mathrm{h}$ & Yield/\% & $M_{\mathrm{n}}$ & Mn Calc & PDI \\
\hline 1 & 2 & $250: 1: 1$ & 110 & 3 & 13.0 & 440 & 3705 & 1.03 \\
2 & 2 & $250: 1: 1$ & 110 & 6 & 12.4 & 440 & 3534 & 1.03 \\
3 & 2 & $250: 1: 1$ & 110 & 12 & 11.2 & 420 & 3190 & 1.03 \\
4 & 2 & $250: 1: 1$ & 110 & 24 & 12.0 & 450 & 3420 & 1.02 \\
5 & 2 & $250: 1: 1$ & 110 & 48 & 13.4 & 450 & 3819 & 1.03 \\
6 & 2 & $250: 1: 1$ & 60 & 12 & 12.0 & 460 & 3420 & 1.03 \\
7 & 2 & $250: 1: 1$ & 80 & 12 & 11.4 & 460 & 3249 & 1.03 \\
8 & 2 & $100: 1: 1$ & 110 & 12 & 13.2 & 420 & 3762 & 1.03 \\
9 & 2 & $500: 1: 1$ & 110 & 12 & 12.3 & 410 & 3505 & 1.03 \\
11 & 2 & $750: 1: 1$ & 110 & 12 & 10.2 & 410 & 2850 & 1.03 \\
12 & 1 & $250: 1: 1$ & 110 & 12 & 8.20 & 270 & 2451 & 1.01 \\
13 & 1 & $250: 1: 1$ & 110 & 24 & 9.00 & 280 & 2565 & 1.02 \\
\hline
\end{tabular}




\begin{tabular}{|c|c|c|c|c|c|c|c|c|}
\hline 14 & 3 & $250: 1: 1$ & 110 & 12 & - & - & - & - \\
\hline 15 & 4 & 250:1:1 & 110 & 12 & - & - & - & - \\
\hline 16 & 6 & 250:1:1 & 110 & 12 & - & - & - & - \\
\hline 17 & 7 & 250:1:1 & 110 & 24 & - & - & - & \\
\hline
\end{tabular}

${ }^{\mathrm{a}}$ By ${ }^{1} \mathrm{H}$ NMR analysis, ${ }^{\mathrm{b}}$ (F.W.[M]/[BnOH])(conversion), ${ }^{\mathrm{C}}$ Obtained from GPC analysis times 0.56

In conclusion, we have investigated the manganese coordination chemistry of a number of [2 +2$]$ type Schiff-base macrocycles and find that in most cases the macrocycle has a preference for binding two 5-coordinate distorted trigonal bi-pyramidal or square pyramidal manganese centres. Related bis(imino)phenols on reaction with $\mathrm{MnCl}_{2}$ afford salt complexes. Application of these complexes as pre-catalysts for the ROP of $\varepsilon$-caprolactone was disappointing with conversions $<15 \%$ observed at most temperatures when using $\mathbf{1}$ or $\mathbf{2}$, whilst complexes $\mathbf{3}$ and $\mathbf{4}$ and the salt complexes were inactive. These results suggest that the combination of manganese and Schiff-base type ligation is not suited to the ROP of $\varepsilon$-caprolactone. Investigations into other combinations of manganese and other ligand sets are on-going in our laboratory.

\section{Experimental}

All manipulations were carried out under an atmosphere of nitrogen using standard Schlenk line and cannula techniques or a conventional $\mathrm{N}_{2}$ filled glove box. Solvents were refluxed over the appropriate drying agents, and distilled and degassed prior to use. Elemental analyses were performed at London Metropolitan University. NMR spectra were recorded on a Varian VXR $400 \mathrm{~S}$ spectrometer at $400 \mathrm{MHz}$, a Gemini at $300 \mathrm{MHz}$ or a Bruker DPX300 spectrometer at $300 \mathrm{MHz}\left({ }^{1} \mathrm{H}\right)$ and $75.5 \mathrm{MHz}\left({ }^{13} \mathrm{C}\right)$ at $298 \mathrm{~K}$; chemical shifts are referenced to the residual protio impurity of the deuterated solvent. EPR spectroscopy was performed on an X-band ER200-D spectrometer (Bruker Spectrospin) interfaced to an ESP1600 computer and fitted with a liquid helium flow cryostat (ESR-900; Oxford Instruments), and the spectra 
were simulated with Simfonia. IR spectra (KBr discs) were recorded on a Perkin-Elmer 577 or 457 grating spectrophotometer. DSC analyses of polymer samples were performed on a TA Instruments DSC Q 1000. Matrix Assisted Laser Desorption/Ionization-Time Of Flight (MALDI-TOF) mass spectrometry was performed on Bruker autoflex III smart beam in linear mode. MALDI-TOF mass spectra were acquired by averaging at least 100 laser shots. 2,5-Dihydroxylbenzoic acid was used as matrix and tetrahydrofuran as solvent. Sodium chloride was dissolved in methanol and used as the ionizing agent. Samples were prepared by mixing $20 \mu \mathrm{l}$ of polymer solution in tetrahydrofuran $(2 \mathrm{mg} / \mathrm{ml})$ with $20 \mu \mathrm{l}$ of matrix solution $(10 \mathrm{mg} / \mathrm{ml})$ and $1 \mu \mathrm{l}$ of a solution of ionizing agent $(1 \mathrm{mg} / \mathrm{ml})$. Then $1 \mathrm{ml}$ of these mixtures was deposited on a target plate and allowed to dry in air at room temperature. The [2 + 2] macrocycles were prepared as described in the literature. [5] All other chemicals were obtained commercially and used as received unless stated otherwise.

Synthesis of $\left\{\mathrm{MnCl}_{4} \mathrm{Mn}\left[2,2^{\prime}-\left(\mathrm{CH}_{2} \mathrm{CH}_{2}\right)\left(\mathrm{C}_{6} \mathrm{H}_{4} \mathrm{NH}\right)_{2}-2,6-\left(4-\mathrm{MeC}_{6} \mathrm{H}_{3} \mathrm{OH}\right)\right]_{2}\right\}$ (1)

To the ligand $\left[2,2^{\prime}-\left(\mathrm{CH}_{2} \mathrm{CH}_{2}\right)\left(\mathrm{C}_{6} \mathrm{H}_{4} \mathrm{~N}\right)_{2}-2,6-\left(4-\mathrm{MeC}_{6} \mathrm{H}_{3} \mathrm{OH}\right)\right]_{2}(0.50 \mathrm{~g}, 0.73 \mathrm{mmol})$ in toluene $\left(30 \mathrm{~cm}^{3}\right)$ was added one equivalent of $\mathrm{MnCl}_{2}(0.082 \mathrm{~g}, 0.65 \mathrm{mmol})$, and the system was refluxed for $12 \mathrm{~h}$. Following removal of volatiles in-vacuo, the residue was extracted in $\mathrm{MeCN}\left(30 \mathrm{~cm}^{3}\right)$, affording on prolonged standing at room temperature small, orange-red crystals of 1 in $68 \%$ yield $(0.38 \mathrm{~g})$. Calculated for $\mathrm{C}_{48} \mathrm{H}_{43} \mathrm{Cl}_{4} \mathrm{Mn}_{2} \mathrm{~N}_{5} \mathrm{O}_{2} \cdot \mathrm{MeCN}$ : C, 59.19; H, 4.57; N, 8.28; Found: C, 59.54; H, 4.88; N, 8.56 \%. IR (cm $\left.{ }^{-1}\right)$ : 3431 (bw), 2965 (m), 2903 (w), 2806 (w), 2712 (w), 2602 (w), 2503 (w), 2247(w), 1635 (s), 1591 (m), 1540 (s), 1487 (m), 1447(w), 1401(w), 1375 (w), 1330 (w), 1299 (s), 1262 (s), 1240 (m), 1215 (m), 1184 (m), 1101 (s), 1106 (s), 1023 (s), 873 (w), 803 (s), 758 (s), 701 (m), 671 (m), 597 (w), 574 (w), 534 (w), 502 (w),

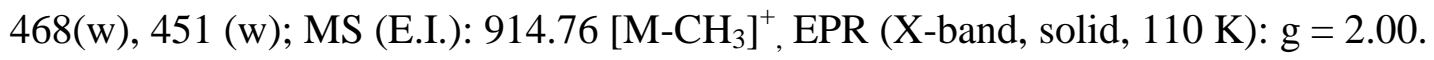

Synthesis of $\left\{\mathrm{MnCl}_{4} \mathrm{Mn}\left[2,2^{\prime}-\left(\mathrm{CH}_{2} \mathrm{CH}_{2}\right)\left(\mathrm{C}_{6} \mathrm{H}_{4} \mathrm{NH}\right)_{2}-2,6-\left(\mathrm{p}-t-\mathrm{BuC}_{6} \mathrm{H}_{3} \mathrm{O}\right)\right]_{2}\right\}$ (2) 
As for 1, but using $\left\{\left[1,2-(\mathrm{N})_{2} \mathrm{C}_{6} \mathrm{H}_{4}\right] \mathrm{CH}\left[\mathrm{CH}_{2}\left(\mathrm{p}-\mathrm{t}-\mathrm{BuC}_{6} \mathrm{H}_{2} \mathrm{OH}\right)\right]\right\}_{2}(0.50 \mathrm{~g}, 0.65 \mathrm{mmol})$ and $\mathrm{MnCl}_{2}(0.082 \mathrm{~g}$, 0.65 mmol) affording 2 as orange/red blocks, $54 \%$ yield (0.36 g). Calculated for $\mathrm{C}_{53} \mathrm{H}_{53} \mathrm{Cl}_{4} \mathrm{Mn}_{2} \mathrm{~N}_{4} \mathrm{O}_{2} \cdot \mathrm{CH}_{3} \mathrm{CN}$ : C, 61.32; H, 5.24; N, 6.62; Found: C, 61.24; H, 5.31; N, 6.75 \%. IR (cm $\left.{ }^{-1}\right)$ : 3412 (bm), 3053 (w), 2953 (m), 2866 (w), 1634 (s), 1587 (m), 1537 (s), 1503 (w), 1484 (m), 1461 (w), 1397 (w), $1361(\mathrm{w}), 1331(\mathrm{w}), 1241(\mathrm{~m}), 1182(\mathrm{~m}), 1102(\mathrm{w}), 1058(\mathrm{w}), 1022(\mathrm{~m}), 885(\mathrm{w}), 862(\mathrm{w}), 828(\mathrm{w}), 794$ (w), $757(\mathrm{~m}), 688(\mathrm{w}), 624(\mathrm{w}), 596(\mathrm{w}), 573(\mathrm{w}), 537(\mathrm{w}), 494(\mathrm{w}), 475(\mathrm{w}) ;$ MS (E.I.): 1016 [M] ${ }^{+}$; EPR (X-band, solid, $110 \mathrm{~K})$ : g = 2.04.

\section{Synthesis of $\left[(\mathrm{MnCl})_{2} 2,2^{\prime}-\mathrm{O}\left(\mathrm{C}_{6} \mathrm{H}_{4} \mathrm{~N}=\mathrm{CH}\right)_{2} 4-\mathrm{MeC}_{6} \mathrm{H}_{3} \mathrm{O}\right](3)$}

As for 1, but using $\left[2,2^{\prime}-\mathrm{O}\left(\mathrm{C}_{6} \mathrm{H}_{4} \mathrm{~N}=\mathrm{CH}\right)_{2} 4-\mathrm{MeC}_{6} \mathrm{H}_{3} \mathrm{OH}\right]\left(\mathrm{L}^{\prime} \mathrm{H}_{3}\right)(0.5 \mathrm{~g}, 0.76 \mathrm{mmol})$ and $\mathrm{MnCl}_{2}(0.19 \mathrm{~g}, 1.5$ mmol) affording 3 as orange/red blocks, $54 \%$ yield ( $0.35 \mathrm{~g})$. The complex can be recrystallized from either acetone or acetonitrile. Calculated for $\mathrm{C}_{44} \mathrm{H}_{36} \mathrm{Cl}_{2} \mathrm{Mn}_{2} \mathrm{~N}_{4} \mathrm{O}_{4} \cdot \mathrm{CH}_{3} \mathrm{CN}$ (sample dried in-vacuo for $2 \mathrm{~h}$, -3MeCN): C, 60.94; H, 4.34; N, 7.06; Found: C, 60.61; H, 3.99; N, 7.36 \%. IR (cm ${ }^{-1}$ ): 3435 (bm), 3057 (w), 2958 (w), 2867 (w), 1625 (s), 1592 (s), 1537 (s), 1486 (m), 1454 (m), 1396 (m), 1362 (w), 1341 (w), 1318 (w), $1238(w), 1221(\mathrm{~s}), 1181(\mathrm{~m}), 1109(\mathrm{~m}), 1057(\mathrm{w}), 1024(\mathrm{~s}), 983(\mathrm{w}), 935(\mathrm{w}), 893(\mathrm{w}), 865 \mathrm{w}(\mathrm{w}), 838$ (w), 798 (m), 777 (w), $757(w), 701(w), 669(w), 631(w), 568(w), 517(w), 469(w), 454(w)$; MS (E.I.): $848.25[\mathrm{M}]^{+}$. EPR (X-band, solid, $\left.298 \mathrm{~K}\right): 2.00$.

\section{Synthesis of $\left[(\mathrm{MnCl})_{2} 2,2^{\prime}-\mathrm{O}\left(\mathrm{C}_{6} \mathrm{H}_{4} \mathrm{~N}=\mathrm{CH}\right)_{2} 4-t-\mathrm{BuC}_{6} \mathrm{H}_{3} \mathrm{O}\right]$ (4)}

As for 1, but using $\left\{\left[2,2^{\prime}-\mathrm{O}\left(\mathrm{C}_{6} \mathrm{H}_{4} \mathrm{~N}=\mathrm{CH}\right)_{2} 4-t-\mathrm{BuC}_{6} \mathrm{H}_{3} \mathrm{OH}\right](0.5 \mathrm{~g}, 0.67 \mathrm{mmol})\right.$ and $\mathrm{MnCl}_{2}(0.17 \mathrm{~g}, 1.35$ mmol) affording 4 as orange/red blocks, yield $50 \%$ (0.31g). Calculated for $\mathrm{C}_{50} \mathrm{H}_{48} \mathrm{Cl}_{2} \mathrm{Mn}_{2} \mathrm{~N}_{4} \mathrm{O}_{4}$ : C, 63.23; H, 5.09; N, 5.90; Found: C, 63.10; H, 5.06; N, 6.16 \%. IR (cm $\left.{ }^{-1}\right)$ : 3428 (bs), 3057 (w), 2964 (w), 2905(w), 1625 (s), 1593 (s), 1541 (s), 1484 (s), 1450 (s), 1395 (m), 1340 (m), 1237 (m), 1215 (s), 1180 (m), 1106 (m), 1065 (m), 1035 (m), 937 (w), 860 (w), 837 (m), 802 (m), 755 (m), $713(w), 566(w), 511(w), 475$ (w); MS (E.I.): 932.51[M] $]^{+}$.EPR (X-band, solid, $\left.298 \mathrm{~K}\right): 2.05$. 
Synthesis of $\left[(\mathrm{MnCl})_{2}(\mathbf{I I I})\right] \cdot 2 \mathrm{MeCN}(5 \cdot 2 \mathrm{MeCN})$.

To a Schlenk flask containing ligand $\mathbf{I I I H}_{4}(1.00 \mathrm{~g}, 1.13 \mathrm{mmol})$ and $\mathrm{MnCl}_{2}(0.29 \mathrm{~g}, 2.3 \mathrm{mmol})$ was added toluene (30 ml) and the system was then refluxed for $12 \mathrm{~h}$. On cooling, volatiles were removed and the residue was extracted into warm acetonitrile $(20 \mathrm{ml})$. Small orange/brown prisms formed on prolonged standing (2 to 3 days) at ambient temperature. Yield 0.85 g, $71 \%$. Calculated for $\mathrm{C}_{58} \mathrm{H}_{60} \mathrm{Cl}_{2} \mathrm{Mn}_{2} \mathrm{~N}_{4} \mathrm{O}_{8} \cdot 2 \mathrm{MeCN}$ : C, 65.32; H, 5.84; N, 7.37; Found: C, 65.14; H, 5.77; N, 7.46 \%. IR (cm $\left.{ }^{-1}\right)$ : 2308w, 2279w, 1651w, 1604m, 1596m, 1575m, 1539w, 1316m, 1261s, 1193m, 1094bs, 1022bs, 876w, 801s, 768w, 742m, 722m. MS (E.I. positive): 1098.9 5 $\mathrm{MeCN}, 1022.45$ - Cl. M.S. (solid, APCI, ASAP) [17]: 1098.9 5· MeCN, 1057.95.

Synthesis of [2,6-( $\left.\mathrm{ArNHCH})_{2}-4-\mathrm{MeC}_{6} \mathrm{H}_{2} \mathrm{O}\right]\left[\mathrm{MnCl}_{3}(\mathrm{NCMe})\right](\mathbf{6})\left(\mathrm{Ar}=2,4-\mathrm{Me}_{2} \mathrm{C}_{6} \mathrm{H}_{3}\right)$.

As for 1, but using 2,6-(2,4- $\left.\mathrm{Me}_{2} \mathrm{C}_{6} \mathrm{H}_{3} \mathrm{NCH}\right)_{2}-4-\mathrm{MeC}_{6} \mathrm{H}_{2} \mathrm{OH}$ (1.00 g, $\left.2.70 \mathrm{mmol}\right)$ and $\mathrm{MnCl}_{2}(0.34$ g, 2.7 mmol) affording 6 as red prisms, 79 \% (1.22 g). Calculated for $\mathrm{C}_{27} \mathrm{H}_{30} \mathrm{Cl}_{3} \mathrm{MnN}_{3} \mathrm{O}$ : C, 56.51; H, 5.27; N, 7.32; Found: C, 56.99; H, 5.29; N, 7.54 \%. IR ( $\left.\mathrm{cm}^{-1}\right)$ : 3361 (w), 2358 (w), 2295 (w), $2268(w), 2242(w)$, 1627 (s), 1595 (s), 1538 (s), 1313 (s), 1282 (s), 1262 (s), 1234 (m), 1201 (m), 1170 (m), 1148 (m), 1115 (m), 1060 (m), 1030 (m), 987 (m), 928 (w), 897 (m), $877(w), 857(w), 820(\mathrm{~m}), 812(\mathrm{w}), 722(\mathrm{~s}), 661(\mathrm{w})$; MS (nanoelectrospray): 371.2 (cation $+\mathrm{H})$.

Synthesis of $\left\{\left[2,6-(\mathrm{ArNHCH})_{2}-4-\mathrm{Me}-\mathrm{C}_{6} \mathrm{H}_{2} \mathrm{O}\right] \mathrm{MnCl}\right\}_{2}\left[\mathrm{MnCl}_{4}\right] \cdot 8 \mathrm{CH}_{2} \mathrm{Cl}_{2}\left(7 \cdot 8 \mathrm{CH}_{2} \mathrm{Cl}_{2}\right)\left(\mathrm{Ar}=4-\mathrm{MeC}_{6} \mathrm{H}_{4}\right)$. As for 1, but using 2,6-(4- $\left.\mathrm{MeC}_{6} \mathrm{H}_{4} \mathrm{NCH}\right)_{2}-4-\mathrm{MeC}_{6} \mathrm{H}_{2} \mathrm{OH}(0.92 \mathrm{~g}, 2.7 \mathrm{mmol})$ and $\mathrm{MnCl}_{2}(0.34 \mathrm{~g}, 2.7 \mathrm{mmol})$ affording 7 as red prisms on crystallization from either dichloromethane or acetonitrile, 89 \% (1.31 g). Calculated for $\mathrm{C}_{92} \mathrm{H}_{88} \mathrm{Cl}_{6} \mathrm{Mn}_{3} \mathrm{~N}_{8} \mathrm{O}_{4} \cdot \mathrm{CH}_{2} \mathrm{Cl}_{2}$ (sample dried for 1 h in-vacuo): C, 60.96; H, 4.95; N, 6.12; Found: C, 61.36; H, 4.90; N 6.83 \%. IR (cm $\left.{ }^{-1}\right)$ : 2243 (w), 1632 (s), 1593 (s), 1533 (s), 1340 (s), 1319 (s), 1278 (s), 1262 (s), 1229 (m), 1211 (m), 1195 (m), 1107 (m), 1061 (m), 1016 (m), 991 (m), 897 (w), 880 (w), 
$847(\mathrm{w}), 834(\mathrm{~m}), 820(\mathrm{w}), 779(\mathrm{w}), 722(\mathrm{~s}), 703(\mathrm{w}), 689(\mathrm{w}), 661(\mathrm{w}), 590(\mathrm{w}), 546(\mathrm{w}), 516(\mathrm{~m}), 494(\mathrm{~m})$; MS (nanoelectrospray): 1137 (salt - anion - 2LH - 2Cl), 1104 (salt - L - p-tolylN).

Ring opening polymerization. Typical polymerization procedures in the presence of one equivalent of benzyl alcohol (Table 4, run 1) are as follows. A toluene solution of $2(0.010 \mathrm{mmol}$, in $1.0 \mathrm{~mL}$ toluene $)$ and $\mathrm{BnOH}(0.010 \mathrm{mmol})$ were added into a Schlenk tube in the glove-box at room temperature. The solution was stirred for $2 \mathrm{~min}$, and then $\varepsilon$-caprolactone $(2.5 \mathrm{mmol})$ along with $1.5 \mathrm{~mL}$ toluene was added to the solution. The reaction mixture was then placed into an oil bath pre-heated to the required temperature, and the solution was stirred for the prescribed time. The polymerization mixture was then quenched by addition of an excess of glacial acetic acid $(0.2 \mathrm{~mL})$ into the solution, and the resultant solution was then poured into methanol (200 mL). The resultant polymer was then collected on filter paper and was dried in vacuo.

\section{X-ray Crystallography}

Diffraction data were collected on CCD area detector diffractometers: Bruker SMART 1K for 1·3MeCN, 3. $\mathrm{C}_{2} \mathrm{H}_{6} \mathrm{O}$, Agilent Xcalibur EOS for 2, 3·4MeCN, 4· MeCN, Bruker APEX II for 5·2MeCN and 6. [18] Full details are presented in Table 5. Data were corrected for absorption and Lp effects. Synchrotron radiation at Daresbury Laboratory Station 9.8 was used for $\mathbf{1} \cdot 3 \mathrm{MeCN}, \mathbf{3} \cdot \mathrm{C}_{2} \mathrm{H}_{6} \mathrm{O}$, and $\mathbf{5} \cdot 2 \mathrm{MeCN}$. Structures were solved by direct or iterative methods and refined by full-matrix least squares on $F^{2}$. [19] For 2 the methyl groups on $t \mathrm{Bu}$ group at $\mathrm{C}(22)$ were modelled as disordered over two sets of positions with major component 60(3) \%. For $4 \cdot \mathrm{MeCN}$ the methyl groups on $t \mathrm{Bu}$ group at $\mathrm{C}(21)$ were modelled as disordered over two sets of positions with major component 52.8(7) \% and the $\mathrm{MeCN}$ of crystallisation was modelled as a diffuse area of electron density by the Platon 'Squeeze' procedure due to severe disorder. [20] For 5·2MeCN the $t \mathrm{Bu}$ group at C(7) was modelled as disordered over two sets of positions with major component 56.0(18) \%. Provisional crystal data for $7 \cdot 8 \mathrm{CH}_{2} \mathrm{Cl}_{2}$ : orange crystals, orthorhombic, space group $\mathrm{Pbcn}$, unit cell: $a=$ 25.057(3), $b=18.987(2), c=24.022(3), V=11429(4) \AA^{3}$, crystal size $1.36 \times 0.48 \times 0.19 \mathrm{~mm}^{3}, T=150 \mathrm{~K}$. Four unique $\mathrm{CH}_{2} \mathrm{Cl}_{2}$ solvent molecules of crystallisation; one of these four was modelled by the Platon 
'Squeeze' procedure [20]; all show evidence of disorder. The crystals desolvated rapidly and the apparent twinning could not be resolved.

CCDC 1415950-1415956 contain the supplementary crystallographic data for this paper. These data can be obtained free of charge from The Cambridge Crystallographic Data Centre via www.ccdc.cam.ac.uk/data_request/cif.

Acknowledgements - We thank Sichuan Normal University and the National Natural Science Foundation of China (grants 51443004 and 51273133) for financial support. The Special Funds for sharing large precision equipment (no. DJ2014-22) at Sichuan Normal University is also thanked. The STFC is thanked for the award of beam-time at Daresbury (Station 9.8) and Drs J.E. Warren, S.J. Teat and T.J. Prior are thanked for scientific support at the beam line. The EPSRC is thanked for a travel award to CR. The National Mass Spectrometry Service at Swansea and Dr Kevin Welham (University of Hull) are both thanked for mass spectrometry data. We wish to acknowledge the use of the EPSRC's Chemical Database Service hosted by the RSC.

References

[1] I. Bratko and M. Gómez, Dalton Trans. 2013, 42, 10664-10681 and references therein.

[2] S. Anbu, M. Kandaswamy, P. Suthakaran, V. Murugan and B. Varghese, J. Inorg. Biochem. 2009, 103, 401-410.

[3] (a) N.H. Pilkington and R. Robson, Aust. J. Chem. 1970, 23, 2225-2236. (b) M. Bell, A.J. Edwards, B.F. Hoskins, E.H. Kachab and R. Robson, J. Am. Chem. Soc. 1989, 111, 3603-3610; (c) B. Bosnich, Inorg. Chem. 1999, 38, 2554-2562; (d) S.R. Koruoju, N. Mangayarkarasi, S. Ameerunisha, E.J. Valente and P.S. Zacharias, Dalton Trans. 2000, 2845-2852; (e) U. Casellato, S. Tamburini, P. Tomasin and P. Vigato, Inorg. Chimica Acta, 2004, 357, 4191; (f) W. Huang, H.-B. Zhu and S.-H. Guo, Coord.Chem. Rev. 2006, 250, 414-423; (g) P.A. Vigato, S.Tamburini and L. Bertolo, Coord.Chem. Rev. 2007, 251, 1311-1492; (h) V. Lozan, C. Loose, J. Kortus and B. Kersting, Coord.Chem. Rev. 2009, 253, 2244-2260. 
[4] A. Arbaoui, C. Redshaw and D.L. Hughes, Chem. Commun. 2008, 4717-4720.

[5] (a) F. H. Allen, Acta Cryst., 2002, B58, 380; (b) For $\mathbf{I H}_{2}$ see A. Arbaoui, C. Redshaw and D. L. Hughes. Supramol. Chem. 2009, 21, 35-43.

[6] About a third of the structures are acetate bridged species and around $20 \%$ are high nuclearity manganese complexes.

[7] See for example, (a) K.S. Banu, T. Chattopadhyay, A. Banerjee, M. Mukherjee, S. Bhattacharya, G.K. Patra, E. Zangrando and D. Das, Dalton Trans. 2009, 40, 8755-8764. (b) A. Jana, N. Aliaga-Alcalde, E. Ruiz and S. Mohanta, Inorg. Chem. 2013, 52, 7732-7746.

[8] J. R. Anacona, E. Bastardo and J. Camus, Transition metal chem. 1999, 24, 478-480.

[9] Q.-H. Xia,-H.-Q. Ge, C.-P. Ye, Z.-M. Liu,-and K.-X. Su, Chem. Rev. 2005, 105, 1603 - 1662.

[10] B.B. Idage, S.B. Idage, A.S. Kasegaonkar and R.V. Jadhav, Materials Science and Engineering B, 2010, 168, 193-198.

[11] (a) J.-C. Jiang, Z.-L. Chu, W. Huang, G.Wang and X.-Z. You, Inorg. Chem. 2010, 49, 5897-5911. (b) R. Golbedaghi, S. Salehzadeh, H.R. Khavasi and A.G. Blackman, Polyhedron, 2014, 68, 151-156.

[12] S. Blanchard, G. Blondin, E. Rivière, M. Nierlich and J.-J. Girerd, Inorg. Chem. 2003, 42, 4568-4578. [13] L. Han, J. Du, H. Yang, H. Wang, X. Leng, A. Galstyan, S. Zarić and W.-H. Sun, Inorg. Chem. Comm. 2003, 6, 5 - 9 .

[14] A search of the CSD for the $\left[\mathrm{MnO}_{2} \mathrm{~N}_{2} \mathrm{Cl}\right]_{2}$ core afforded 4 hits: (a) M.A.S. Goher, M.A.M. Abu-Youssef, F.A. Mautner and A. Popitsch, Polyhedron 1993, 12, 1751-1756. (b) S. Onaka, L. Hong, M. Ito, T. Sunahara, H.Imai and K. Inoue, J. Coord. Chem. 2005, 58, 1523-1530. (c) J.-W. Zhang, H.-S. Wang and Y. Song, Inorg. Chem. Comm. 2011, 14, 56-60. (d) M. Alexandru, M. Cazacu, A. Arvinte, S. Shova, C. Turta, B.C. Simionescu, A. Dobrov, E.C.B.A. Alegria, L.M.D.R.S. Martins, A.J.L. Pombeiro and V.B. Arion, Eur. J. Inorg. Chem. 2014, 120-131. (e) CSD system: F. H. Allen, Acta Cryst., 2002, B58, 380-388. [15] These complexes were also found to be inactive as catalysts for benzene oxidation using hydrogen peroxide, X. Liu, L.Wu, X.Wang, K.-Q. Zhao and C. Redshaw, unpublished results. 
[16] S. Blanchard, G. Blondin, E. Rivière, M. Nierlich and J.-J. Girerd, Inorg. Chem. 2003, 42, 4568-4578 and references therein.

[17] APCI refers to the ionization method, Atmospheric Pressure Chemical Ionization, in which samples introduced into the APCI source via an Atmospheric Solids Analysis Probe (ASAP) are vaporized then ionized using a corona discharge $(\sim 4 \mu \mathrm{A})$. The benefit of using ASAP is that samples can be introduced at ambient temperature as solids or in solution, then the temperature in the source is increased until the sample vaporizes.

[18] (a) SMART, SAINT, and APEX 2 software for CCD diffractometers. (1997-2012). Bruker AXS Inc., Madison, USA. (b) Agilent (2013). CrysAlis PRO. Agilent Technologies, Yarnton, Oxfordshire, England. [19] (a) G.M. Sheldrick, Acta Cryst. 2015, C71, 3-8. (b) L. Palatinus and G. Chapuis, J. Appl. Cryst. 2007, 40, 786-790.

[20] (a) A.L. Spek, Acta Crystallogr. 1990, A46, C34. (b) P.v.d. Sluis and A.L. Spek, Acta Crystallogr. 1990, A46, 194.

Table 5. Crystallographic data for complexes $\mathbf{1} \cdot 3 \mathrm{MeCN}, 2$ and $3 \cdot \mathrm{C}_{3} \mathrm{H}_{6} \mathrm{O}$.

$\begin{array}{cccc}\text { Compound } & \mathbf{1} & \mathbf{2} & \mathbf{3} \cdot \mathrm{C}_{3} \mathrm{H}_{6} \mathrm{O} \\ \text { Formula } & \mathrm{C}_{46} \mathrm{H}_{40} \mathrm{~N}_{4} \mathrm{O}_{2} \mathrm{Mn}_{2} \mathrm{Cl}_{2} \cdot 3 \mathrm{CH}_{3} \mathrm{CN} & {\left[\mathrm{C}_{52} \mathrm{H}_{52} \mathrm{~N}_{4} \mathrm{O}_{2} \mathrm{MnCl}\right]\left[\mathrm{C}_{2} \mathrm{H}_{3} \mathrm{NCl}_{3} \mathrm{Mn}\right]} & \mathrm{C}_{42} \mathrm{H}_{30} \mathrm{~N}_{4} \mathrm{O}_{4} \mathrm{Mn}_{2} \mathrm{Cl}_{2} \cdot \mathrm{C}_{3} \mathrm{H}_{6} \mathrm{O} \\ \text { Formula weight } & 1055.66 & 1057.71 & 893.56 \\ \text { Crystal system } & \text { Triclinic } & \text { Triclinic } & \text { monoclinic } \\ \text { Space group } & P \overline{1} & P & P 2_{1} / c \\ \text { Unit cell dimensions } & & & \\ a(\AA) & 11.2704(15) & 10.7462(3) & 11.3736(14) \\ b(\AA) & 11.895(2) & 12.3269(5) & 14.4597(18) \\ c(\AA) & 20.373(4) & 21.8883(7) & 26.105(3) \\ \alpha\left({ }^{\circ}\right) & 106.635(10) & 84.265(3) & 90 \\ \beta\left({ }^{\circ}\right) & 94.676(12) & 89.403(2) & 100.577(3) \\ \gamma\left({ }^{\circ}\right) & 103.633(13) & 66.420(3) & 90 \\ V\left(\AA^{3}\right) & 2510.4(8) & 2642.70(17) & 420.3(9) \\ Z & 2 & 2 & 4 \\ \text { Temperature }(\mathrm{K}) & 160(2) & 293 & 160(2) \\ \text { Wavelength }(\AA) & 0.6942 & 0.71073 & 0.6931\end{array}$




$$
\text { (g. } \mathrm{cm}^{-3} \text { ) }
$$

Absorption coefficient

$$
\left(\mathrm{mm}^{-1}\right)
$$

Transmission factors (min./max.)

Crystal size $\left(\mathrm{mm}^{3}\right)$

$$
\theta(\max )\left(^{\circ}\right)
$$

Reflections measured

Unique reflections

$$
R_{\text {int }}
$$

Reflections with $F^{2}>2 \sigma\left(F^{2}\right)$

Number of parameters

$$
R_{1}\left[F^{2}>2 \sigma\left(F^{2}\right)\right]
$$

$w R_{2}$ (all data)

GOOF, $S$
0.71

0.934 and 0.977

$0.09 \times 0.04 \times 0.03$

29.3

17406

12080

0.020

9383

615

0.046

0.119

1.00

0.52 and -0.54
1.329

1.406

0.72

0.72

0.931 and 1.000

$0.40 \times 0.30 \times 0.20$
29.2

25184

12137

0.028

8754

642

0.046

0.114

1.05

0.90

0.938 and 0.986

$0.09 \times 0.06 \times 0.02$

26.0

22979

8858

0.115

4928

528

0.071

0.169

0.46 and -0.45

1.17 and -1.20 
Table 5 con't. $\quad$ Crystallographic data for complexes $3 \cdot 4 \mathrm{MeCN}, \mathbf{4}, 5 \cdot 2 \mathrm{MeCN}$ and 6.

\begin{tabular}{|c|c|c|c|c|}
\hline Compound & 3· $4 \mathrm{MeCN}$ & 4 & $\mathbf{5} \cdot 2 \mathrm{MeCN}$ & 6 \\
\hline Formula & $\mathrm{C}_{42} \mathrm{H}_{30} \mathrm{~N}_{4} \mathrm{O}_{4} \mathrm{Mn}_{2} \mathrm{Cl}_{2} \cdot 4 \mathrm{C}_{2} \mathrm{H}_{3} \mathrm{~N}$ & $\mathrm{C}_{48} \mathrm{H}_{42} \mathrm{~N}_{4} \mathrm{O}_{4} \mathrm{Mn}_{2} \mathrm{Cl}_{2} \cdot \mathrm{C}_{2} \mathrm{H}_{3} \mathrm{~N}$ & $\mathrm{C}_{58} \mathrm{H}_{60} \mathrm{~N}_{2} \mathrm{O}_{4} \mathrm{Mn}_{2} \mathrm{Cl}_{2} \cdot 2 \mathrm{C}_{2} \mathrm{H}_{3} \mathrm{~N}$ & {$\left[\mathrm{C}_{25} \mathrm{H}_{27} \mathrm{Cl}_{2} \mathrm{~N}_{2} \mathrm{O}\right]\left[\mathrm{C}_{2} \mathrm{H}_{3} \mathrm{NMnCl}_{3}\right]$} \\
\hline $\begin{array}{l}\text { Formula } \\
\text { weight }\end{array}$ & 999.69 & 960.69 & 1139.98 & 573.83 \\
\hline $\begin{array}{l}\text { Crystal } \\
\text { system }\end{array}$ & Triclinic & Monoclinic & Triclinic & Monoclinic \\
\hline $\begin{array}{l}\text { Space group } \\
\text { Unit cell } \\
\text { dimensions }\end{array}$ & $P \overline{1}$ & $P 2 / c$ & $P \overline{1}$ & $C 2 / c$ \\
\hline$a(\AA)$ & $9.0678(3)$ & 13.5740(14) & $9.251(3)$ & $8.6706(4)$ \\
\hline$b(\AA)$ & $14.5779(6)$ & $9.1261(11)$ & $12.594(4)$ & $23.5547(10)$ \\
\hline$c(\AA)$ & 18.8111(7) & $22.833(3)$ & $12.781(4)$ & 27.6317(12) \\
\hline$\alpha\left({ }^{\circ}\right)$ & $72.522(3)$ & 90 & $82.736(5)$ & 90 \\
\hline$\beta\left({ }^{\circ}\right)$ & $83.680(3)$ & $102.45(1)$ & $83.976(5)$ & 97.6782(7) \\
\hline$\gamma\left({ }^{\circ}\right)$ & $87.859(3)$ & 90 & $70.543(5)$ & 90 \\
\hline$V\left(\AA^{3}\right)$ & 2357.39(16) & $2762.0(6)$ & $1389.6(8)$ & $5592.7(4)$ \\
\hline Z & 2 & 2 & 1 & 8 \\
\hline $\begin{array}{c}\text { Temperature } \\
\text { (K) }\end{array}$ & 143 & 293 & $120(2)$ & $120(2)$ \\
\hline $\begin{array}{c}\text { Wavelength } \\
(\AA)\end{array}$ & 0.71073 & 0.71073 & 0.6897 & 0.71073 \\
\hline $\begin{array}{l}\text { Calculated } \\
\text { density } \\
\left(\mathrm{g} \cdot \mathrm{cm}^{-3}\right)\end{array}$ & 1.408 & 1.155 & 1.362 & 1.363 \\
\hline Absorption & & & & \\
\hline $\begin{array}{c}\text { Coefficient } \\
\mathrm{t}\left(\mathrm{mm}^{-1}\right)\end{array}$ & 0.70 & 0.60 & 0.55 & 0.78 \\
\hline $\begin{array}{c}\text { Transmission } \\
\text { factors } \\
\text { (min./max.) }\end{array}$ & 0.909 and 1.000 & 0.909 and 1.000 & 0.937 and 0.984 & 0.811 and 0.926 \\
\hline $\begin{array}{l}\text { Crystal size } \\
\left(\mathrm{mm}^{3}\right)\end{array}$ & $0.30 \times 0.25 \times 0.20$ & $0.30 \times 0.20 \times 0.20$ & $0.12 \times 0.08 \times 0.03$ & $0.28 \times 0.15 \times 0.10$ \\
\hline$\theta(\max )\left(^{\circ}\right)$ & 29.0 & 29.1 & 24.0 & 30.5 \\
\hline $\begin{array}{l}\text { Reflections } \\
\text { measured }\end{array}$ & 22126 & 13163 & 10273 & 33498 \\
\hline $\begin{array}{l}\text { Unique } \\
\text { reflections }\end{array}$ & 10861 & 6314 & 4710 & 8544 \\
\hline$R_{\text {int }}$ & 0.027 & 0.055 & 0.056 & 0.033 \\
\hline $\begin{array}{l}\text { Reflections } \\
\quad \text { with } \\
F^{2}>2 \sigma\left(F^{2}\right)\end{array}$ & 8698 & 3892 & 3112 & 6516 \\
\hline $\begin{array}{l}\text { Number of } \\
\text { parameters }\end{array}$ & 601 & 294 & 383 & 330 \\
\hline $\begin{array}{l}R_{1}\left[F^{2}>\right. \\
\left.2 \sigma\left(F^{2}\right)\right]\end{array}$ & 0.041 & 0.053 & 0.084 & 0.037 \\
\hline$w R_{2}$ (all data) & 0.094 & 0.118 & 0.273 & 0.101 \\
\hline GOOF, S & 1.05 & 0.92 & 1.06 & 1.01 \\
\hline $\begin{array}{c}\text { Largest } \\
\text { difference } \\
\text { peak and } \\
\text { hole } \\
\left(\mathrm{e} \AA^{-3}\right)\end{array}$ & 0.43 and -0.29 & 0.41 and -0.48 & 0.69 and -0.72 & 0.42 and -0.29 \\
\hline
\end{tabular}

